дение высш. проф. образования «Волгогр. Гос. ун-т», Ин-т права. - Т. 2/ авт. коллектив тома: Н.В. Висков [и др.]. - Волгоград: Изд-во ВолГУ, 2013. - 356 с.

12. Правонарушения в Республике Беларусь: статистический сборник/ Национальный статистический комитет Республики Беларусь. - Минск, 2015.

13. Общая статистика преступности за 2015 год/ Министерство внутренних дел Республики Беларусь// [Электронный доступ]. - 2016. - Режим доступа: http://mvd.gov.by/main.aspx?guid=256493. Дата доступа: 27.03.2016.

\title{
ENFORCEMENT OF ARBITRAL AWARDS
}

\section{A. V. Kazlouski}

The article deals with the procedure of enforcement of national and foreign arbitral awards.

Arbitration is an effective means of dispute resolution in the commercial sphere. It can be explained by the fact that in international trade it is often easier to enforce an arbitration award in a foreign country than to enforce a judgment of the court. The successful party in an international commercial arbitration expects the award to be performed without any delay [1, p. 430]. The problem of the order of the award execution is not new to our time, but it is important for any country to keep up with the experience of the international community in the legal regulation in this sphere. There are many disputable issues in this field. In the paper we will focus on the following issues: the definition of what the award is; identification of its «nationality»; choice of the applicable procedure of the award enforcement.

It is to be mentioned, that there is no internationally accepted definition of the term «award». Indeed, none is to be found in the international conventions dealing with arbitration. Even though the New York Convention is directed to the recognition and enforcement of awards, the nearest it comes to is the following definition: «The term 'arbitral awards' shall include not only awards made by arbitrators appointed for each case but also those made by permanent arbitral bodies to which the parties have submitted.» [2].

Under the Belarusian legislation the arbitral award is the decision on the merits by an arbitration tribunal in an arbitration, and is analogous to a judgment in a court of law. This is the result of the arbitration process.

There are two mechanisms of enforcement depending on the nationality of the award. So, first of all it is necessary to identify the nationality of the award. In accordance with the national legislation, the award issued by the arbitral tribunal, which is situated in the Republic of Belarus, is considered as a national award. The mechanism of national award enforcement, established by the Belarusian national law, is the following. The successful party submits an application to the Belarusian economic court, which checks the grounds for refusing the enforcement. It is to be mentioned, that these grounds are of a 
purely procedural nature. Economic court does not check the award on the merits. If the grounds for enforcement refusing do not exist, the court on the basis of application issues a writ of execution, which is the document to be submitted to the authorities for the recovering the debt. Thus, we underline that for the enforcement of national arbitral awards the executive document is to be obtained.

The second mechanism is applied to foreign awards, which should be recognized by the economic court in Belarus. The recognition procedure is established by Belarusian national legislation and international legal treaties. The main treaty in this sphere is New York Convention, which is directed at the recognition and enforcement of international awards. According to Art. I of the Convention it shall apply to the recognition and enforcement of arbitral awards made in the territory of a State other than the State where the recognition and enforcement of such awards are sought, and arising out of differences between persons, whether physical or legal. It shall also apply to arbitral awards not considered as domestic awards in the State where their recognition and enforcement are sought [2]. The winning party submits an application to Economic court for the recognition and enforcement of foreign arbitral award. The economic court checks the grounds for refusing of recognition, which are fixed in Art. V of New York Convention. The New York Convention does not permit any review on the merits of an award to which the Convention applies. The grounds for refusal of recognition and enforcement set out in the New York Convention are exhaustive. If the court does not find the grounds for refusing, the award is recognized in the Republic of Belarus. So, it is necessary to distinguish between recognition and enforcement. Enforcement goes a step further than recognition. The court which is prepared to grant enforcement of an award will do so because it recognizes the award as validly made and binding upon the parties to it and, therefore, suitable for enforcement. In this context, the terms «recognition» and «enforcement» do run together. One is a necessary part of the other $[1$, p. 435]. But only after the recognition the national court can issue a writ of execution.

International trade is developing day by day. However, during the human interaction disputes cannot be avoided. And if arbitration is an effective way to resolve disputes, the perfection of the legislation will make our country more attractive for investors.

\section{Literature}

1. Redfern A. Law and practice of international commercial arbitration. - London: Sweet \& Maxwell, 2004. - 659 p.

2. Интернет-адрес: http://www.uncitral.org/pdf/english/texts/arbitration/NY-conv/NewYork-Convention-E.pdf 